\title{
Stock Market Development of Middle East and North Africa (MENA) Region
}

\author{
Wan Fauziah Wan Yusoff ${ }^{1,2}$, Instisar J. Guima ${ }^{2}$ \\ ${ }^{1}$ Director Centre for Business and Entrepreneurship, University Tun Hussein Onn Malaysia, Parit Raja Batu Pahat Johor, Malaysia \\ ${ }^{2}$ Faculty of Technology Management and Business, University Tun Hussein Onn Malaysia, Parit Raja Batu Pahat Johor, Malaysia
}

Email address:

fauziahy@uthm.edu.my (W. F. W. Yusoff), intisar.tripoli@gmail.com (I. J. Guima)

\section{To cite this article:}

Wan Fauziah Wan Yusoff, Instisar J. Guima. Stock Market Development of Middle East and North Africa (MENA) Region. International Journal of Business and Economics Research. Vol. 4, No. 3, 2015, pp. 163-171. doi: 10.11648/j.ijber.20150403.19

\begin{abstract}
Financial markets play important roles for economic growth as they facilitate the flow of resources to the most productive investment opportunities and help in terms of efficient allocation of credit in the economy. Recognizing the important roles of stock market on economic growth, prudential international institutions such as World Bank, IMF and ADB pursued stock market development programs for emerging markets in developing nations. Hence, this study sought to investigate the determinants of development in capital markets in the MENA region from the perspective of three countries Egypt, Saudi Arabia and Tunisia. Secondary data for the ten years period of 1992-2012 were used to model the factors influencing the development of their stock markets. Using Correlation analysis it has been revealed that, macro-economic factors such as exchange rate, oil rent, income per capita, inflation, domestic savings and interest rate can be used to study development capital markets. The analysis also reported significant relationship between stock market development and some variables for some countries and irrelevant to others. The variations in results are explained by the economic and legal environment in every country and show some policy options. The findings are interesting in the sense that they provide variations of the determinants of the stock market development in the region. This would open area for research that is concerned with enhancing the collective development of the stock markets in the region through complementary and synergies.
\end{abstract}

Keywords: Capital Market Development, MENA, Egypt, Saudi, Tunisia, Macroeconomic

\section{Introduction}

Over the last decade, stock markets have received a great deal of attention, both as a source of financial development and ultimately economic growth, and in the context of large swings in stock market valuation. Capital markets allow for wider ownership among the public, thereby distributing risks and wealth amongst smaller investors (Beck \& Levine, 2004). For investors, they provide an effective vehicle for making investment choices which suit their own preferences of risk and returns based on available information. As such, capital markets help the economy to generate more savings and productive investments. Moreover, stock markets can attract foreign portfolio capital and increase domestic resource mobilization, expanding the resources available for investment in developing countries, including of course MENA region countries. Both firms and individuals will benefit from developed stock markets in the sense that firms will lead a lower cost of equity capital and individual will get an effective hedge price risk. In order to enhance the efficiency of investment it is important to constantly develop the capital markets in a country.

Recognizing the importance of stock market on economic growth, prudential international institutions such as World Bank, IMF and ADB pursued stock market development programs for emerging markets in developing nations during 80s and 90s and they found that, emerging stock markets have experienced considerable development since the early 1990s. The market capitalization of emerging market countries has more than doubled over the past decade growing from less than $\$ 2$ trillion in 1995 to about $\$ 5$ trillion in 2005 (Yartey, 2008).

There has been a considerable research on determinants of financial sector development of late. Demirguc-Kunt et al. (1996) indicate that economies without well-functioning stock markets may suffer from three types of imperfections: first, 
opportunities for risk diversification are limited for investors and entrepreneurs, second, firms are unable to optimally structure their financing packages and third, countries without well-functioning markets lack information about the prospects of firms whose shares are traded, thereby restricting the promotion of investment and its ${ }^{\text {ee }}$ efficiency. While Levine and Zervos (1996a, b) provided empirical evidence on the major theoretical debates about the linkages between stock markets and long-run economic growth using data on 41 countries from 1976 to 1993 . Their result showed that stock market liquidity is positively and significantly correlated to current and future rates of economic growth, capital accumulation, and productivity improvements, even after controlling for economic, political and other factors. In addition, Yartey and Adjasi (2007) have analyzed the relationship between financial market development and macroeconomic variables, financial reform, and other country -specific factors, and the relationships among the development of the various parts of a financial system. In other words, stock market complements the development of other parts of the financial system. Adam and Tweneboah (2009) observe a triangular causal relationship that FDI stimulates economic growth, economic growth promotes stock market development; and FDI promote stock market development related study, foreign investment is associated with institutional and regulatory reform, adequate disclosure and listing requirements and fair trading practices which inspire greater confidence in domestic markets. This increases the investor's base and participation which leads to more capital flows (Yartey, 2008). It is clear that from the previous studies financial markets tend to develop as the economy grows and financial reform progresses.

The rest of the paper is organised as follows. In section 2, we discuss the evolution of stock market in the MENA Region, followed by determinants of Stock Market Development in MENA in section 3. Section 4 discusses the data sources and variables definition for our empirical works. Section 5 discusses findings of the study. This paper ends up with conclusion and implications in section 6 .

\section{Literature Review}

\subsection{Evolution of Stock Market in the MENA Region}

Since 1990's, most of the MENA countries began to liberalize their stock markets. However, there are very few researches discussing on such reform as an important amount of theoretical and empirical literature. According to Samny et al.,(2007) "the whole MENA region is classified as a bank based economy due to bank as a dominant financial institution in MENA region. Thus, the agenda of reform of the 1990s initiated the development of stock markets in other countries of MENA region. New capital markets have been developed in many of the MENA countries with an aim to increase private investment and protecting investors in stimulating markets. As a result, growth performance, GDP per worker, and total factor productivity levels in the MENA region since the early 1980s has been near zero and negative, closer to Latin America and lagging far behind East Asia (Bosworth \& Collins, 2003).

The growth and development performance of the Middle East and North Africa (MENA) region presents one of the major deviation that current economics literature seeks to resolve, which is how to reconcile the existence of massive natural resources with the high unemployment, low growth and the general underdevelopment of the region. MENA region debated extensively on the issues that have been arising from internal economic policies, lack of integration in the world economy, less developed financial institutions and unstable investment climate followed with low human capital development (Dutt \& Ros, 2008). Americans and Europeans have growing interest in the MENA region expecting high stock returns. Ahmed (2011) mentioned that due to newly launched markets in the MENA region led to increase global integration with $55 \%$ of Foreign Direct Investment (FDI) through merger and acquisition during the period of 1991 to 2000.

During the year 1950s to the late 1970s, the economic structure of the MENA region have been characterized as an import substituting regime including strict controls on international trade, overhead exchange rates and rationing foreign exchange and credit market. Dahi (2011), mentioned that due to hikes in petroleum prices in the early 70s, growth and development indicators in the MENA region improved rapidly. The sudden increase in investment and growth rates in the oil-exporting countries spread to the rest of the region through increases in worker remittances, and capital flows. In addition, gross capital formation jumped to exceptionally high rates generating a locomotive effect on growth rates and overall standards of living. In large part due to the collapse in oil prices in the 1980s and 1990s growth rates in the region experienced marked declines. Low growth rates failed to provide rapidly expanding labor force with sufficient employment opportunities and led to a deterioration of living standards and a rise in poverty rates. Later between 2000 and 2005 , the stock market evidenced with some changes as compared to the underdeveloped listings with few numbers of companies listed and thin trading during 1990s. Figures 1 to 3 show that the stock markets in Egypt Saudi Arabia and Tunisia. Figure1: Stock Market development of Egypt, Saudi Arabia and Tunisia (World Bank, 2014). 


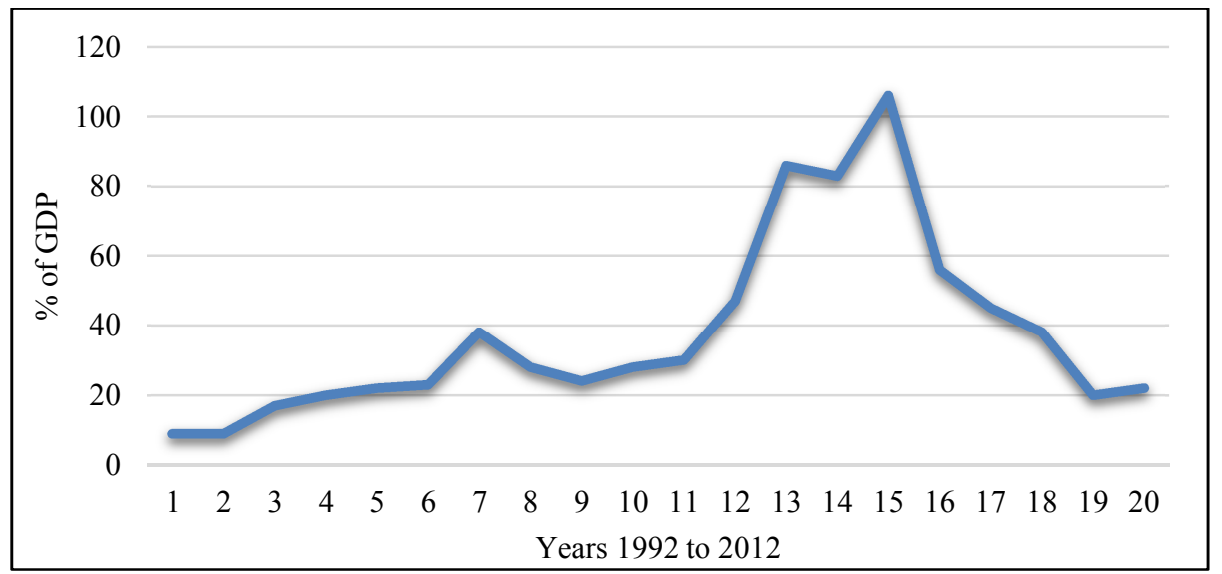

Figure 1. Stock Market Development in term of market capitalization of listed companies (\%) in Egypt from 1992 to 2012.

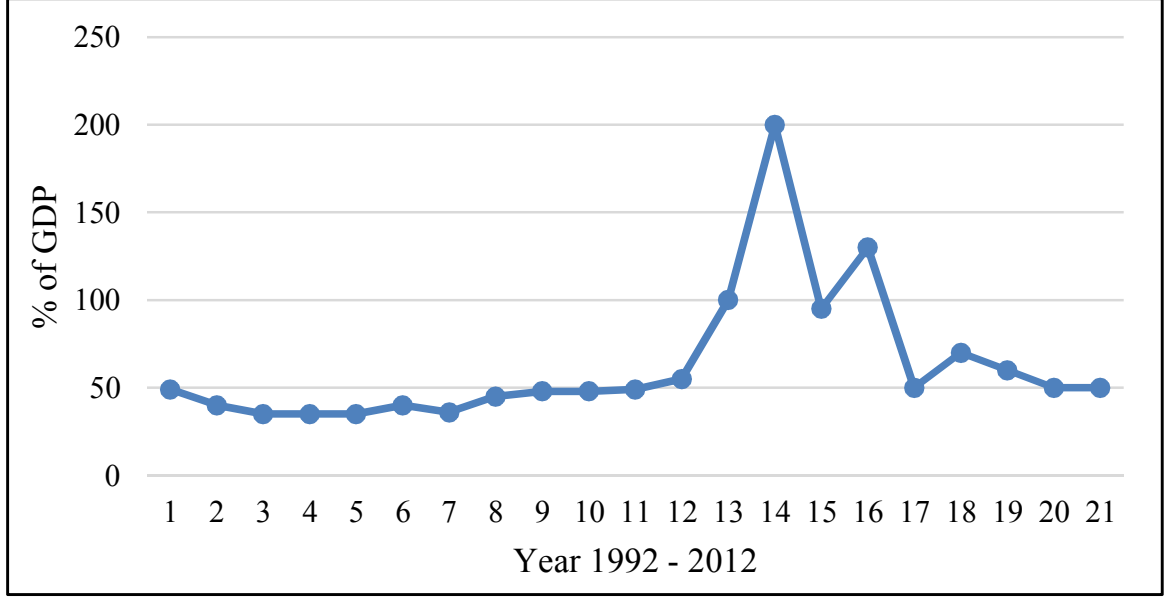

Figure 2. Stock Market Development in term of market capitalization of listed companies (\%) in Saudi Arabia from 1992 to 2012.

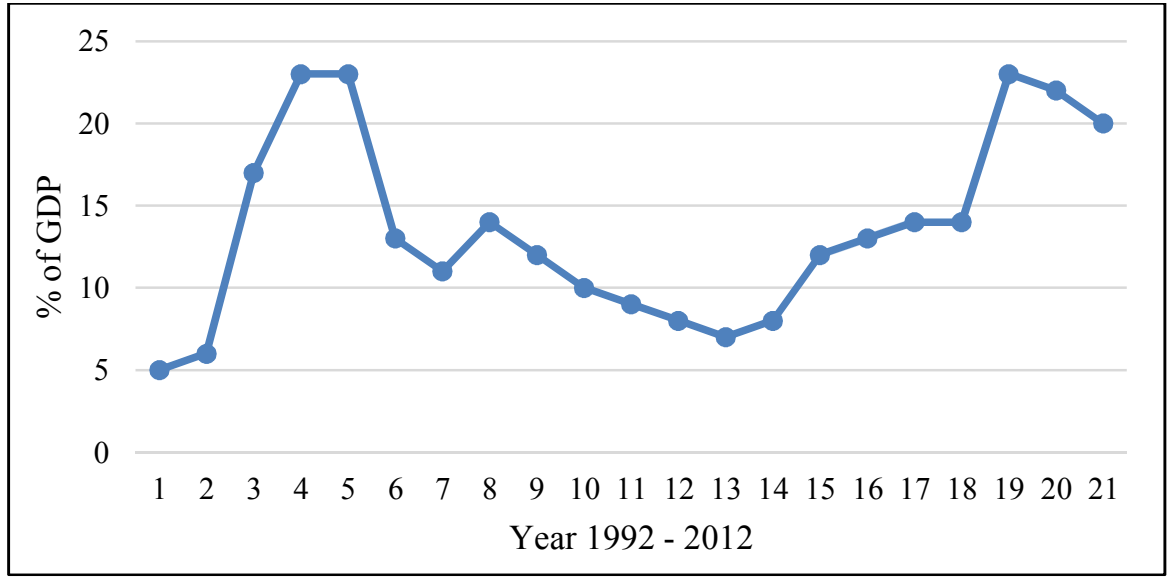

Figure 3. Stock Market Development in term of market capitalization of listed companies (\%) in Tunisia 1992 to 2012.

During 90s both markets have sluggishly developed as new markets with the Egyptian one having stronger momentum. In contrast the Tunisian market showed a strong and active development in the early 90s only to retreat vastly in 1997 coinciding with the Far East Financial crisis. Egypt and Saudi Arabia who were both oil exporters at the time have less impacted by this crisis. The Egyptian and Saudi markets then developed fast in the start of the Millennium, when Saudi market has shown an impressive jump in activities in the middle of the first decade, followed by the Egyptian market. The depression of the market continued for the half of the first decade in Tunisia in response to decline in the oil rent of the country. In the Second half of the decade and up to 2012 the Egyptian and Saudi markets have retreated substantially in response to the global financial crisis in 2008. Both countries have suffered from lower oil price and decline in FDI flows. In Tunisia the path showed a slightly different scenario. The global financial crisis has altered the growth trend of the 
market but not to bend down. The market continued its upward trend only to be halted by the political instability that followed the Tunisian revolution in 2011. Hence, the paper discusses the performance of capital markets in MENA by focusing the analysis on a sample of main three (3) countries i.e. Egypt, Saudi Arabia and Tunisia. They are believed to play integral roles as far as economic development is concerned.

\subsection{Determinant of Stock Market Development in MENA}

Empirical evidence finds that a well-developed stock market can foster economic growth in the long run. This is in line with theories that a well - functioning stock market can promote economic development by fueling the engine of growth through faster capital accumulation and by tuning it through better resource allocation (Corporale et al, 2004). The stock markets in those countries are one of the fastest growing emerging stock markets and therefore worth studying. Stock market development is proxy of market capitalization as a proportion of GDP. The primary role of a stock market is to provide a market where financial instruments can be traded in a regulated environment without constraint. According to Levive (2005) stock market is a vital part of any economic system in which ownership can be bought or sold. A stock exchange and its presence in an economic system can be justified by the following functions it performs- channels savings into investments. It converts investments into cash, thus supplying market liquidity and helps in evaluating and managing securities.

\subsubsection{Exchange Rate}

The literature in economics debate that exchange rate would affect the development of the stock markets through two main channels: money supply and flow of FDI, in a free market setting (Aydemir \& Demirhan 2009). First if the exchange rate is high compared to other currencies this assumedly will lead to higher domestic consumption and higher money supply consequently. This on the stock market front would lead to elevation of the market activities. Second if the exchange rate is relatively higher than other compared currencies this might lead to deter investor from coming to a country affecting negatively foreign investment flows. A decline in stock prices makes foreign investors sell the financial assets they hold in the respective currency which subsequently, leads to currency depreciation (Desislava, 2005). It must be stressed here that factors such as currency volatility and governmental restrictions would impact on such assumptions. In our sample there are three patterns of exchange rate policies that are pursued for different economic and political reasons.

\subsubsection{Oil Rent}

Oil rent is the third variable in the paper's model. Oil rents are calculated here as percentage of GDP. They represent the difference between the value of crude oil production at world prices and total costs of production (Khrawish et al., 2010). It was decided here to include this variable as a result of the importance of oil price and oil revenues in the economies of MENA countries. It makes a leading income for oil exporters and importers alike. Oil sales for oil exporter country feed directly into national accounts, while they feed into oil importers accounts through remittances, trade and aids.

\subsubsection{GDP Per Capita, PPP (Current International \$)}

It is essential in an economic and financial model to have a variable that reflects the income. Here the economic growth is not a focus of the paper; rather it is the factors that influence the development of the stock market. High income levels associated with high oil price during 70 s were used an argumentum to avoid establishment of stock market and apply free market mechanism in MENA (Khrawish et al., 2010). The economic difficulties of the 80 s that continued over the $90 \mathrm{~s}$ with declining personal income in those countries encouraged the countries in the region to adopt economic reforms that include establishment and develop stock markets as explained above. Generally the income level is growing however with various patterns. It is clear that Saudi Arabia has steadily increased its GDP/capita during the period.

\subsubsection{Inflation, Consumer Prices (Annual \%)}

A positive relationship between the development of the financial system and economic growth took place in the economic literature (King \& Levine, 1993a; Levine and Zervos, 1996, 1998). However, Boyd et al. (2001) show that there is a significant, and economically important, negative relationship between inflation and both stock market development and banking sector activity. Azariadis and Smith (1996) emphasize the importance of threshold level of inflation in the relationship between inflation and financial sector performance. The negative consequence of inflation on financial sector efficiency becomes effective once the rate of inflation exceeds some threshold. Inflation trend as shown in the graph below presents a similar trend across the sample. A U shape with second half of 90 s as the trough was depicted. Inflation started to rise at the beginning of 2000s and in the case of Egypt stuck in inflation spiral ended with the global financial crisis in 2008 and the political upheaval of 2011.

\subsubsection{Gross Savings (\% of GDP)}

The gross saving rate is calculated is calculated as gross national income less total consumption, plus net transfers then relate it to GDP. Like banks, stock markets convey saving to investment projects. Usually, the larger the saving rate, the higher the flow of capital to stock markets. The paper expects a positive effect of the saving rate on the stock market size. Savings in the sample differentiated as a result of macroeconomic and oil price factors. While Egypt and Tunisia who are witnessing a huge reduction in their oil production due to depleting reserves have kept their saving rates constant around $20 \%$ of GDP for most of the period, are witnessing now a declining rate started as an effect of the global financial crisis and was further deteriorated by the political upheaval in both countries. In Saudi Arabia saving correlated with oil price levels, and has two distinctive phases. The first phase was in 90s when it was locked around $20 \%$ levels. In 2000s the savings broke out of the previous level to reach $50 \%$ level, with short interruption in 2008 coincided with the global financial crisis. 


\subsubsection{Interest Rate Short Term Official (Annual Average)}

An interest rate is the cost of borrowing money. Interest rate is mainly an incentive that is linked to the banking sector activities. Since both the banking sector and stock markets intermediate savings towards investment projects, they can be either complements or substitutes. From the "demand for funds" Mahmudu et al.,(2009) states that in a perfect market with symmetric information, the market value of all the securities issued by a firm is independent of the firm's source of finance and consequently firms could go either to the banking sector or to the stock markets to finance their capital. However, asymmetric and imperfect information dominates in the real world. Some countries also distort the financing choices through taxes, subsidies and regulations. Thus, debt or equity financing does matter. From the "supply of funds" point of view, in the short run the relationship might be negative because of arbitrage between interest rates and stock market returns, but in the medium and longer term investors would probably want to diversify their financial assets and spread their savings between the banking sector and stock markets. The substitutes or complements issue could be country specific due to special incentives to obtain debt or equity financing.

\section{Methodology}

The study employed secondary data and a descriptive approach. This method is similar to previous studies by Garcia and Liu (1999) and Yartey (2008). The data were collected through various economic and countries reports to model the impact of macroeconomics on the development of the stock markets. Macroeconomic factors data included exchange rate, oil rent, GDP, inflation, saving and interest rate for year 1992 to 2012.

To test the impact of the above determinates on stock market development, Pearson Correlation analysis was employed. Studies by Yartey (2008) and Lazaridis and Trofornidis (2006) have used the same analysis while researching on relationship among variables. The correlation matrix is an important indicator that tests the linear relationship, between the variables. The matrix also helps to determine the strength of the variables in the model, that is, which variable best explains the relationship between stock market development and its determinants.

\section{Results and Discussions}

Table 1 displays a summary of the descriptive statistics of the data in this study. The table shows that of three countries stock market development of Saudi Arabia found to be higher that Egypt and Tunisia. Similarly, for all determinates of stock market development, Saudi Arabia was also higher that Tunisia and Egypt especially in term of Exchange rate compare to US Dollar, GDP/capital, Saving and Oil Rent. At the same time Saudi Arabia also found to have lower in interest rate compared to Egypt and Tunisia.

Table 1. Descriptive Statistics of all variables of this study.

\begin{tabular}{|c|c|c|c|c|c|c|c|c|c|c|c|c|}
\hline & \multicolumn{4}{|l|}{ Egypt } & \multicolumn{4}{|c|}{ Saudi Arabia } & \multicolumn{4}{|l|}{ Tunisia } \\
\hline & Min & $\operatorname{Max}$ & Mean & $\begin{array}{l}\text { Standard } \\
\text { Deviation } \\
\end{array}$ & Min & $\operatorname{Max}$ & Mean & $\begin{array}{l}\text { Standard } \\
\text { Deviation } \\
\end{array}$ & Min & $\operatorname{Max}$ & Mean & $\begin{array}{l}\text { Standard } \\
\text { Deviation } \\
\end{array}$ \\
\hline $\begin{array}{l}\text { Stock market } \\
\text { development }\end{array}$ & 0.077887 & 1.053 & 0.37061 & 0.27238 & 28.71519 & 196.7072 & 60.75 & 41.676 & 5.2525 & 24.06997 & 13.832 & 5.6052841 \\
\hline Exchange Rate & 3.321748 & 6.196 & 4.606773 & 1.183891 & 3.745 & 3.75 & 3.749 & 0.0013 & 0.8844 & 1.561892 & 1.2337 & 0.1881853 \\
\hline Oil Rent & 3.426476 & 13.09 & 8.296694 & 2.748284 & 22.32513 & 58.87597 & 39.11709 & 9.7618 & 1.2278 & 5.918521 & 3.1946 & 1.2285493 \\
\hline Inflation & 2.269757 & 18.31683 & 8.200388 & 4.585492 & -1.34789 & 9.868752 & 1.950 & 2.9008 & -1.3478 & 9.868752 & 1.9504 & 2.9008654 \\
\hline Saving & 13.02803 & 34.18904 & 21.14153 & 4.740665 & 15.39863 & 52.75268 & 33.39 & 13.205 & 14.502 & 22.66396 & 20.677 & 2.0013875 \\
\hline Interest Rate & 11.0083 & 20.3283 & 13.84476 & 2.350152 & 0.694467 & 6.667167 & 3.731 & 2.0220 & 2 & 9.625 & 4.4293 & 2.1614897 \\
\hline
\end{tabular}

Table 2 presents the correlation matrix of the variables in this study. The table shows that there is positive correlation between stock market development and oil rent, inflation, GDP/capita for all countries; other variables vary as stock markets in Egypt and Tunisia are positively correlated with exchange rate while market in Saudi is negatively correlated with Exchange rate. With regard to savings it is negatively correlated with stock markets in Egypt and Tunisia while it is positively correlated in Saudi Arabia. Lastly all markets have a negative correlation with interest rate.

Table 2. Pearson correlation co-efficient between variables.

\begin{tabular}{|c|c|c|c|c|c|c|c|c|c|c|c|c|c|c|c|c|c|c|c|c|c|}
\hline & \multicolumn{7}{|l|}{ Egypt } & \multicolumn{7}{|c|}{ Saudi Arabia } & \multicolumn{7}{|c|}{ Tunisia } \\
\hline & CMD & EX & OR & INF & GDPC & SAV & INT & CMD & EX & OR & INF & GDPC & SAV & INT & CMD & EX & OR & INF & GDPC & SAV & INT \\
\hline CMD & 1.00 & & & & & & & 1.00 & & & & & & & 1.00 & & & & & & \\
\hline EX & 0.71 & 1.00 & & & & & & -0.58 & 1.00 & & & & & & 0.55 & 1.00 & & & & & \\
\hline OR & 0.40 & 0.40 & 1.00 & & & & & 0.77 & -0.54 & 1.00 & & & & & 0.57 & 0.25 & 1.00 & & & & \\
\hline INF & 0.78 & 0.85 & 0.20 & 1.00 & & & & 0.70 & -0.13 & 0.66 & 1.00 & & & & 0.85 & 0.78 & 0.66 & 1.00 & & & \\
\hline GDPC & 0.18 & 0.18 & 0.62 & 0.19 & 1.00 & & & 0.42 & -0.04 & 0.59 & 0.68 & 1.00 & & & 0.24 & -0.39 & 0.38 & -0.02 & 1.00 & & \\
\hline SAV & -0.07 & -0.26 & 0.63 & -0.43 & 0.49 & 1.00 & & 0.86 & -0.53 & 0.89 & 0.83 & 0.58 & 1.00 & & -0.52 & -0.44 & -0.36 & -0.05 & -0.27 & 1.00 & \\
\hline INT & -0.66 & -0.65 & 0.21 & -0.81 & 0.25 & 0.71 & 1.00 & -0.47 & -0.17 & -0.39 & -0.68 & -0.43 & -0.49 & 1.00 & -0.63 & -0.89 & -0.27 & -0.85 & 0.37 & 0.32 & 1.00 \\
\hline
\end{tabular}


Over the period of the study it seems that most variables have a strong correlation (positively or negatively) with stock market development. The variables that stand out with weak correlation relationship are GDP/capita in Egypt and in Tunisia, bearing in mind it has not shown a quite significant correlation in Saudi Arabia as well compared to other variables

Appendix 1 summarizes the results. As indicated in the regression statistics R-squared was $0.767,0.675$ and 0.463 for Egyptian, Saudi and Tunisian data respectively. This means that $76 \%$ for Egypt, $67 \%$ for Saudi and $46 \%$ for Tunisia variations from the expected and actual output (dependent variable: stock market development) are explained by the independent variables. These indicate good fit of the regression equation 1 for both Egypt and Saudi Arabia but less robust for Tunisia. Thus, this is a good reflection of the true position that stock market development is determined by the exchange rate, oil rent, inflation, GDP/capita, gross savings and interest rate. Analysis of Variance shows that f-calculated is greater that $\mathrm{f}$ - critical for all country data. This implies that the regression equation 1 was well specified.

\subsection{Exchange Rate}

The original assumption about the exchange rate was that it plays as competitive factor against the domestic investment. Higher exchange rate might deter foreign inflow and volatile exchange rates lead to decline in stock market as witnessed in the Far East financial crisis of 1997. Two countries Egypt and Tunisia have more flexible exchange rate flexible policies. However, EX coefficients proved to be insignificant in the regression. This might be explained by the assumption that the variations of the exchange rates during the period did not cause major impacts on the stock market; also foreign investors might not comprise a significant part of the market yet. While exchange rate in the Saudi regression makes a significant variable despite its inflexible movement.

\subsection{Oil Rent}

This variable was chosen as a result of the importance of oil revenues in the MENA region economies. The regression above revealed interesting findings. The variable is active only in the least oil producing countries Egypt and Tunisia, while it is insignificant in Saudi Arabia. This might traced to different reasons. First, in Saudi Arabia the oil activities are State monopoly and are not integrated in the private sector which is quoted in the stock market. The Tunisian coefficient 2.5 reflects a high contribution and this mirror the contribution of the private sector in the oil sector in Tunisia through stock market. This points toward to an important result which is the significant of stock market in raising fund for petroleum industry.

\subsection{GDP/Capita}

The general assumption is that this variable would have a positive effect on the development of the stock market. The regressions prove that this variable is significant only in Egypt and Saudi Arabia but not in Tunisia. Also they indicate that there are a negative relationship with coefficients of (-0.00011) and (-0.0052) for Egypt and Saudi respectively. While the downside effects look very small on the equations but they say that it is not expected that rise in GDP/capita would lead to a similar rise in stock markets on both countries. It is difficult to explain this result which was witnessed on other international markets, but some reasons could be that overheating of the economies because of unexpected rise in revenue (such as oil price spike) would not lead to a parallel activities rise in stock markets.

\subsection{Inflation}

Inflation variable is significant in Egypt and Tunisia, but not in Saudi Arabia. Inflation as a macroeconomic instability factor theoretically influence stock market in a close economy by the competition between share price and property prices. If share return does not compete with property inflation more investment would be channeled to or asset property markets. While the Egyptian example follow on this explanation with coefficient $(-0.0154)$ which means that any rise of inflation would negatively impact the stock market, it have an opposite effect in Tunisia with coefficient of (1.467) which means that any rise of inflation would positively impact on its stock market.

\subsection{Gross Savings}

Savings according to the regression results are significant in Egypt and Saudi Arabia, while in Tunisia is not so. This result corresponds to the correlation table (2) which shows a weak correlation between savings and stock market development in Egypt and Tunisia, while in the meantime a very strong one in Saudi Arabia. This is interesting in the sense that and as mentioned above that GDP/capita were negatively related to the development of stock market for both countries. Saving seems to turn the risk adverse nature of investors in these countries to expand in stock market activities. In Egypt the coefficient is (0.0346) significantly lower than the Saudi's one which registered (3.098) which help us to explain the spike in stock market development in the period 2004-2006.

\subsection{Interest Rate}

Finally interest rate is significant in Egypt and Saudi Arabia but not in Tunisia. Both have large negative effects with coefficient of (-0.141) and (-6.464) to Egypt and Saudi Arabia respectively. The smaller percentage of Egypt actually is multiplied by a bigger number Mean of (13.84) in comparison to a much lower Mean in Saudi Arabia (3.73).

\section{Conclusions}

Stock market development is an integral part of financial development, which is, in turn, associated with economic growth. Stock markets in MENA however, are relatively new 
in the global economy. Still the heavily regulated economies in MENA are slowing the development of the stock markets and it was therefore important to understand the main determinants that could have a role either in pushing forward or holding them backward. Form the analysis the Saudi's stock market was found to have a heavy influence from variables used in this study. The reason can be attributed to the public ownership of oil and oil facilities that does not allow for transmission of fund between the two entities. While in Egypt and Tunisia who have a more liberated oil sector structure the variable have a significant positive factor. The last interesting findings are that savings make very powerful push to the market in Saudi and to less extent in Egypt. This explains the spikes in the development of stock markets in both countries during 2004-2006. More research should be done in this trend but initially it proves that savings have an effect on turning around the risk adverse culture that prevail in those countries and especially towards newly established stock markets. Savings encourage investors after threshold to increase their activities in stock market having an economic cushion that reduce risk transferring investor from classical financial tools such as banks to stock markets.

\section{Appendix 1}

Regression Model Summary for Egypt

\begin{tabular}{llll}
\hline R Squared & $\mathbf{0 . 7 6 7 4 1 5 2}$ & & \\
\hline Adjusted R Squared & 0.667736 & & Mean Square \\
Observations & 21 & & \\
ANOVA (Analysis of Variance) & Degree of freedom & Sum of Squares & 0.1896764 \\
& 6 & 1.1380582 & 0.024637 \\
Regression & 14 & 0.3449177 & \\
Residual & 20 & & $\mathrm{t}$-Statistics \\
Total & 7.6988496 & & 2.1005459 \\
Calculated F & 0.0008417 & & 0.9256346 \\
Significance F & & Standard Error & 1.7261655 \\
Output of Regression - Co-efficient & Coefficients & 0.7241617 & 1.424578 \\
Predictor- Independent Variable & 1.5211349 & 0.0683815 & 1.3278235 \\
Intercept & 0.0632963 & 0.0268287 & 2.2469014 \\
EX & 0.0463107 & $7.79 \mathrm{E}-05$ & 3.6071926 \\
OR & -0.000111 & 0.011217 & \\
GDPC & -0.0154315 & 0.0154268 & 0.0391038 \\
INF & 0.0346625 & & \\
SAV & -0.1410548 & & \\
INT & & & \\
\hline
\end{tabular}

Regression Model Summary for Saudi Arabia

\begin{tabular}{llll}
\hline R Squared & $\mathbf{0 . 6 7 5 5 7 1 1}$ & & \\
\hline Adjusted R Squared & 0.5365302 & & \\
Observations & 21 & & Mean Square \\
ANOVA (Analysis of Variance) & & Sum of Squares & 3911.4545 \\
& Degree of freedom & 23468.727 & 805.02594 \\
Regression & 6 & 11270.363 & \\
Residual & 14 & 34739.09 & \\
Total & 20 & & -Statistics \\
Calculated F & 4.8587931 & & 1.4226345 \\
Significance F & 0.0070016 & & 1.4203455 \\
Output of Regression-Co-efficient & & Standard Error & 0.2002782 \\
Predictor- Independent Variable & Coefficients & 28277.271 & 1.6887624 \\
Intercept & 40228.222 & 7533.8798 & 0.7186652 \\
EX & -10700.712 & 1.6714238 & 1.8911447 \\
OR & -0.3347497 & 0.0031229 & 1.3565309 \\
GDPC & -0.0052738 & 3.3492691 & 1.6381739 \\
\hline INF & -2.4070032 & 4.7654361 & \\
SAV & 3.0980239 & & \\
INT & -6.4644612 & & \\
\hline
\end{tabular}


Regression Model Summary for Tunisia

\begin{tabular}{llll}
\hline \multicolumn{2}{l}{ Tunisia Regression Model Summary: Dependent variable stock Market Development } & \\
\hline R Squared & 0.4633289 & & \\
Adjusted R Squared & 0.233327 & & \\
Observations & 21 & Mean Square \\
ANOVA (Analysis of Variance) & & Sum of Squares & 48.524759 \\
& Degree of freedom & 291.14855 & 24.08826 \\
Regression & 6 & 337.23564 & \\
Residual & 14 & 628.38419 & \\
Total & 20 & & $\mathrm{t}-$ Statistics \\
Calculated F & 2.0144568 & & 0.5321365 \\
Significance F & 0.1314794 & & 0.0768446 \\
Output of Regression-Co-efficient & & Standard Error & 1.366162 \\
Predictor- Independent Variable & Coefficients & 36.617358 & 0.4243888 \\
Intercept & 19.485432 & 15.993113 & 1.9651291 \\
EX & -1.2289839 & 1.8955825 & 0.4693502 \\
OR & -2.5896729 & 0.0025146 & 0.1748325 \\
GDPC & 0.0010672 & 0.7465542 & 0.7149128 \\
INF & 1.4670753 & 1.8438623 & \\
SAV & -0.3355444 &
\end{tabular}

\section{References}

[1] Aydemir, O. and E. Demirhan (2009), The Relationship between stock returns And Exchange Rates: Evidence from Turkey, International Research Journal of Finance and Economics 23:207-215.

[2] Adam, A. M. and Tweneboah, G. (2008), Macroeconomic Factors and Stock Market Movement: Evidence from Ghanae [Online] Available http://papers.ssrn.com/sol3/papers.cfm?abstract id $=1289842$ [Accessed 8 February 2009].

[3] Ball, R. (2001). The theory of stock market efficiency: accomplishments and limitations. The New Corporate Finance: Where Theory Meets Practice, p.20-33. New York: Irwin

[4] Beck, T. and Levine, R. (2001), Stock Markets, Banks and Growth: Correlation or Causality, Policy Research Working Papers 2670, Washington DC: World Bank.

[5] Beck, T., and Levine, R. (2004). Stock markets, banks and growth: Panel evidence. Journal of Banking and Finance, 28 (3), 423-442.

[6] Beck, T., Demirguc-Kunt, A., and Levine, R. (2003). Law, endowments, and nance. Journal of Financial Economic, 70 (2), 137-181.

[7] Ben Naceur, S., Ghazouani, S., and Omrani, M. (2007). The determinants ofstock market development in the MENA region. Managerial Finance,33 (7), 477-489.

[8] Bosworth, Barry P. and Susan M. Collins, 2003, 'The Empirics of Growth: An Update', Brookings Papers on Economic Activity, 2003 (2), pp. 113-206.

[9] Boyd, J.H., Levine, R., and Smith, B.D. (2001). The impact of in action on financial sector performance. Journal of Monetary Economics, 47 (2),221-248.
[10] Caporale G, Howells, P, Soliman A. (2005). "Endogenous Growth Models and Stock Market Development: Evidence from Four Countries." Review of Development Economics, 9(2): 166-176.

[11] Catalán, Mario, Impavido, Gregorio and Musalem, Alberto R., 2000, "Contractual Savings or Stock Market Development Which Leads?" World Bank Policy Research Working Paper No. 421.

[12] Corporale G.M, Howells P.G and Soliman A.M (2004). Stock Market and Economic Growth: The Causal Linkag. Journal of Economic Development, Volume 29.

[13] Dahi, O. (2011). Understanding the Political Economy of the Arab Revolts. Middle East Report, 259(41), 2-6.

[14] Demirguc-Kunt, Asli, and Ross Levine. (1996). "Stock Markets, Corporate Finance and Economic Growth: An Overview," The World Bank Economic Review 10 (2) Demirguc-Kunt, Asli, and Ross Levine. 1996b. "Stock Market Development and Financial Intermediaries: Stylized Facts," The World Bank Economic Review 10 (2), pp. 291-321.

[15] Desislava, D. (2005) - Estimate the relationship between exchange rates and stock market prices: studied in a multivariate modell Issues in Political Economy, Vol. 14.

[16] Dutt, A. K., \& Ros, J. (2008). International handbook of development economics: Edward Elgar Publishing.Economic research. (2012). Egyptian Stock Exchange Performance. http://www.alexbank.com/Uploads/documents/research/The\% 20Egyptian\%20Stock\%20Exchange\%20Report-\%20January \%202012.pdf

[17] Hamilton, J. D., 2003. What Is an Oil Shock? Journal of Econometrics 113, $363\{398$.

[18] Hinich, M. J., Serletis, A., 2007. Episodic Nonlinear Event Detection in the Canadian Exchange Rate. Journal of the American Statistical Association 102 (477), 68\{74. 
[19] King R.G. and R. Levine. 1993. "Finance and growth: Schumpeter might be right", Quarterly Journal of Economics, Vol.108:717-738.

[20] Khrawish A., Zakaria W., Jaradat M (2010)., The relationships between stock market capitalization rate and interest rate: Evidence from Jordan, $3 \mathrm{BEH}$ - Business and Economic Horizons, Volume 2, Issue 2, , pp. 60-66

[21] Levine, Ross (1996). Stock Markets: A Spur to Economic Growth, Finance and Development Division, the World Bank'sPolicy Research Department.

[22] Levine R. and Zervos A., 1998. Stock Markets, Banks, and Economic Growth. American Economic Review, 88(3), pp. 537-58.

[23] Levine R., Loayza N., and Beck T., 2000. Financial intermediation and growth: Causality and causes. Journal of Monetary Economics, 46, 31-77.

[24] Levine R., Loayza N., and Beck T., 2000b. Finance and the sources of growth. Journal of Financial Economics, 58, 261-300.

[25] Levine, R. (2005). Finance and growth: Theory and evidence. In P. Aghion and S. Durlauf (Eds.), Handbook of economic growth. Elsevier: Amsterdam.

[26] Mahmudul, A., Gazi Salah, U., (2009). "The relationship between interest rate and stock price: Empirical evidence from developed and developing countries," International journal of business and management, Vol.4, No3, pp.43-51.
[27] Naceur S, Ghazouani S, 2007 Does Inflation Impact on Financial Sector Performance in the MENA Region? Review of Middle East Economics and Finance Volume 3, Issue 3 Article 4

[28] Nasrin, A. and Syed, S. H., (2011). - An Empirical Analysis of the Relationship between Macroeconomic Variables and Stock Prices in Bangladesh. Bangladesh Development Studies 44( 4).

[29] Ologunde, A., Elumilade, D., Saolu, T., 2006. "Stock market capitalization and interest rate in Nigeria: A time series analysis," International Research Journal of Finance and Economics, Issue 4, pp.154-67.

[30] Oskooe, S. A. P. (2010). "Emerging Stock market performance and economic growth". American Journal of applied Sciences 7(2): 265-269.

[31] Shan J. (2005). "Does Financial Development Lead Economic Growth? - A Vector Auto-Regression Appraisal". Applied Economics, 37: 1353-1367.

[32] Yartey C.A and Adjasi C.K. 2007. "Stock Market Development in Sub-Saharan Africa: Critical Issues and Challenges." IMF Working Paper No. 07/209.

[33] Yartey, Charles Amo. 2008. "Determinants of Stock Market Development in Emerging Economies: Is South Africa Different?” IMF Working Paper No. 08/32.

[34] World Bank (2014). "World Development Indicators" available at http://data.worldbank.org/news/release-of-world-development -indicators-2014. 